LUBLIN STUDIES IN MODERN LANGUAGES AND

LITERATURE 40(1), 2016, HTTP://WWW.LSMLL.UMCS.LUBLIN.PL, HTTP://LSMLL.JOURNALS.UMCS.PL

Ildiko Csajbok-Twerefou

University of Ghana

P.O. Box 207, Legon, Accra, Ghana

\title{
Popular Culture and Language Etiquette: The Use of Formal and Informal 'you' as Address Forms in Selected Russian and Hungarian Films
}

\author{
ABSTRACT \\ Address forms, as key expressions of politeness, are used in all \\ cultures. They are well displayed in films which exhibit different \\ societies at different times in many cases, and are becoming one of the \\ biggest agents of popular culture, giving great opportunities for their \\ use in sociolinguistic studies. This paper examines the socio-cultural \\ aspects of the use of formal and informal 'you' as address forms \\ through films in Hungarian and Russian languages. It explores the \\ main similarities and differences between the studied societies in \\ terms of the use of "Tu-vous" forms (Brown \& Gilman, 1975). \\ Keywords: politeness; language etiquette; Russia; Hungary; film
}

\section{Introduction}

Politeness as a phenomenon is considered to be an active component of each culture: it has several rules according to the beliefs and traditions of the world's different nations. It is studied by researchers of several disciplines such as psychology, sociology, linguistics and others. During different periods, it varied and the principles of polite behaviour are still changing, since that is often set and influenced by the dominant rulers of the cultural elite of a given state. According to 
C. Félix-Brasdefer (2007:1-3) and G.R. Vlasyan (2011:36), there is no generally accepted classification of the linguistic theory of politeness. There are several existing approaches and concepts, such as politeness as language maxims, or rules; politeness as an ethical category; politeness as the assessment of the status of persons; politeness as conversational contract; courtesy as saving face.

Etiquette, as it is known today as standards of behaviour, was first implemented by the higher class during the era of Enlightenment. However, the earliest written piece on "etiquette" is The Maxims of Ptahhotep from 2,200 BC. The Egyptian text on then-valued behaviour was perhaps written for young men who came from powerful and high-ranking families and who might soon have important duties in higher offices. In The Maxims of Ptahhotep one can see advice regarding communication with people of different social status or ages etc. (http://www.britannica.com/EBchecked/topic/370565/The-Maximsof-Ptahhotep, 2014).

According to Hitchings (2013), the basics of rules and ideas of good manners were adopted from church disciplines of monasteries during the medieval era, though later on they became independent of any religion. This was the basis of the above mentioned etiquette set up by the Enlightenment's elite. We understand etiquette as a set of behaviour that is standardised according to the conventions and expectations of a society, nation, social group etc. and based on traditions and heritage.

Manners and etiquette are closely related, since both of them are based on how to treat people with respect. While manners are mostly taught from early childhood starting in the family, etiquette is related to certain areas, such as business etiquette, work etiquette, etc., therefore it is usually learnt in adulthood. Exceptions may be found in the life of children of different "elites", like monarchs, politicians or others, where etiquette is considered to be very important. Between 1500 and 1900 in many European countries etiquette was a school subject, which shows that it had great importance for "privileged people", as formal education was available only for the upper class. 
Language etiquette is a set of linguistics forms used to express politeness, where by politeness we mean the correct use of earlier acquired manners. Language etiquette therefore is very diverse not only because of the existence of many different languages, but also because of different cultures which define politeness according to their traditions, expectations, etc. An example can be made on the basis of English, the most widely-spoken language in the world, which is often used not according to the British English language etiquette, but to the norms required by other social groups of the former British colonies.

In this paper, a component of language etiquette is examined through feature films. Using different studies on the topic as well as our knowledge of the studied cultures, the occurrence of formal and informal 'you' as address forms in the Hungarian and Russian languagesused in both societies are compared. Since "[f]ilms provide a message of the socio-cultural background of people and information about the reality of appearances, about the language and speech and also about the characters" (Csajbok-Twerefou, 2010:56), they provide a great opportunity to study language etiquette in the two different societies. The objective of the study is to recognize the appearance of formal and informal 'you' as address forms through Hungarian and Russian feature films and to examine the criteria used by the speaker while selecting the appropriate formal or informal 'you'.

Talking about address forms, we refer to words, which directly call the name, status etc. of the partner of communication as well as the use of adequate personal pronouns.

The paper is made up of six sections: after the first section, which is the introduction, Section Two focuses on the examined countries in terms of their geography, history and language, while Section Three introduces popular culture and films. Section Four is devoted to address forms as part of communication and Section Five presents the "Tu-vous" system in Russia and Hungary. The final section concludes the paper.

Hungarian and Russian films which portray similar scenes or are close in theme were chosen and downloaded from the Internet. Here 
are some of the selected Hungarian films: Szeleburdi család 'Giddy Family' (1981), Kemény kalap és krumpliorr 'Clown Hat and Red Nose' (1978), Ismeretlen ismerős 'Unknown Friend' (1989) Csak szex és más semmi 'Just Sex and Nothing Else' (2005), Az 5. iz 'The $5^{\text {th }}$ Taste' (2014), Ámbár tanár úr 'Teacher "Although" (1998), Argó (2007), Zártosztály ‘Asylum' (2014).

Some of the Russian films are as follows: Курьер 'Courier' (1986), Дневник мамы первоклассника 'Diary of a First-Grader's Mum' (2014), Единица с обманом 'Failure Grade with Cheating' (1986), Черная молния 'Black Lightning' (2009), Любовь-морковь 'LoveCarrot' (2007), Любовь-морковь - 2 'Love-Carrot - 2' (2008), Тариф «счастливая семья» Promotion "Happy Family" (2013).

2. Geography, history and languages

Russia is a multiethnic country (Toschenko, 2010), though in Russia $77.8 \%$ of the citizens are ethnic Russians (Census, 2010). While the official language of the country is Russian, several other languages are also recognized in various republics of Russia, and, therefore, many of its citizens are bilingual. In this paper, however, 'Russian' refers to the modern Russian language, and to people who consider the Russian language to be their first language.

Hungary is composed of different ethnic groups; according to historians, Hungarians came to the territory of today's Hungary in 895 from the East, a place near the Urals of today's Russia. During their move from the East, they stayed in several places before settling in Europe and had contact with different nations. Since its conquest, Hungary came through many wars, which led to the mixture of the ethnic-groups. However, even though Hungarians are said to have trekked from near the Ural Mountains to Hungary, the Hungarian language is from the Finno-Ugric language family and it has no common heritage with Slavic or Russian people apart from those which were adopted during their wars and the like. Presently, Hungary is homogeneous in terms of language; in accordance with the 2011 Census, almost $99 \%$ of the people of Hungary refer to the Hungarian language as their first language (2013). 
3. Popular culture and films

According to the Macmillan Online Dictionary (2015), popular culture is "the type of entertainment that most people in a society enjoy, for example films, television programmes, and popular music." In the Soviet Union, many films, television programmes, songs, etc. were produced in the last century, though in the Russian language the term popular culture was used with a negative connotation and mostly referred to the Western culture (Lugovoy 2001; in Csajbok-Twerefou \& Dzahene-Quarshie 2014). Nevertheless, their role was the same as in other parts of the world: "they had some socio-regulatory functions, such as standardization of social, political and cultural behaviour, attitude and interest" (Csajbok-Twerefou \& Dzahene-Quarshie 2014:112). Nowadays the term popular culture in Russia has lost its negative connotation.

In Hungary, the role of popular culture was very similar to that in the Soviet Union. In many cases products of the Western culture were connected with vulgarism, and, therefore, access to them was monitored or even restricted. Many of them were brought to Hungary through secret channels and were duplicated by underground organizations. A change towards the representation of the Western popular culture can be seen from the 1980s, and in recent times, the term popular culture refers to different entertainments enjoyed by people of the society.

According to Sak (2012), the Soviet-Russian film industry goes back to 1896, when the first film was demonstrated. The first Russian film Ponizova freemen/Razin was produced in 1908. Since then the Soviet and Russian film industry distributed thousands of films, though their premieres were closely connected with the economic and social situations in the country. During the First and Second World Wars (1914-1918; 1941-1945 respectively), the numbers of the premieres were lower than before and after the wars. The same tendency is noticed during the last few years of the Soviet era, as well as after the 'birth' of the modern Russian Federation: from 1991 to 
1997 the number of Russian films decreased from 213 to 28 (Fedorov, 2011). Films were produced on many topics, but, especially during the Soviet period, several of them were to display propaganda, packed in different scripts: family life, school, army, urban and rural life of people, etc. All films were censored and because of this some films were screened only after Perestroika (1986) though they were made during the Soviet time. From the beginning of the $21^{\text {st }}$ century, the Russian film industry started production again. Though most films are made by private companies, in many cases films are also sponsored by the Russian government: a number of popular film-series, films for children and other feature films are made.

The Hungarian film industry's history also started in 1896 (Balogh, 2015). It shows many similarities with the Soviet/Russian one, due to the geopolitical location of Hungary. The first Hungarian film was produced, however, earlier than the first Russian one: The Dance was created in 1901, being an illustration to an oral presentation on dance. The first Hungarian feature film came out in 1912. Since then thousands of films of different genres have been created in Hungarian studios, reflecting sometimes the needs, sometimes the politics, the history or the social expectations, as well as the economic situation of Hungary. As in the Soviet Union, in Hungary films were also censored. In 1989, the Hungarian film industry was decentralized and the state stopped sponsoring it. The Hungarian film industry started producing more and more films yearly only from the early 2000s. Recently, there are new Hungarian filmmakers, whose films mainly address contemporary issues of the wider society, or sometimes go back to earlier times (like the Oscar winner Son of Saul (2015).

The beginning of the production of Russian and Hungarian films was different, but at the end of the 1980s the film industry of the examined countries had similar problems: the state had no funds to continue financing the national film industry. Consequently, film production was in great need in both countries. Another similarity can be found in the themes of their films: they were made mediums of education, propaganda and entertainment. It is important to note that in the Soviet Union and later in Russia, as well as in Hungary, some 
films were made specifically for the younger generation. Nonetheless, most Soviet/Russian and Hungarian films portrayed and still portray society, culture, traditions, etc., of the countries describing different eras. For these reasons, films give a great opportunity to analyse the Russian and Hungarian societies from different points of view, including the use of language etiquette.

4. Address forms as parts of communication

People interact in many ways: they speak, write, gesticulate, use different body languages, etc. While writing and speaking, participants of the communication use several forms of address, taking into consideration different aspects. Using the above mentioned Russian and Hungarian feature films, those common rules applied by the interlocutors in the selection of the use of formal or informal 'you' in the two examined languages are presented below.

Normally, when someone needs to use an address form, he or she shall know who will be addressed: one would like to have some information about him or her in order to be able to select the best addressing form. Both in Hungary and Russia, people communicate in formal or informal ways. According to our observation, the definition of formal and informal situations is almost the same for the examined countries. Informal situations mostly occur with family members or close friends, while formal situations do with people outside the mentioned groups, though there may be situations when people who usually interact with each other informally shall use formal patterns. For example, friends during official meetings will (must?) use the formal 'you' and titles and surnames of their interlocutors.

5. The "Tu-vous" forms

Discussing the use of address forms required by environments and situation, in many societies, it is necessary to mention the so-called "Tu-vous" forms. According to Brown \& Gilman (1975), who gave the historical background of the use of those personal pronouns, the Vous form (V) can refer to power, while the Tu form (T) to solidarity. These personal pronouns are "adopted" from French, and have 
become the terminology of sociolinguistics. Their translated equivalents are seen in many other languages: $\mathrm{Du}$ and Sie in German, $m b l$ [ty] and $6 b l / B b l$ [vy] in Russian, Te/Ti and Maga/Maguk and Ön/Önök in Hungarian etc.

Historically, both in Hungary and Russia, the $\mathrm{V}$ form was used in the communication of the elites, while the $\mathrm{T}$ form was used by others. If the interlocutors had different social status, the higher one mostly used the $\mathrm{T}$ form, while the lower one had to use the $\mathrm{V}$ form in their communication. In the Hungarian and Russian languages there are verbs that demonstrate whether the interlocutors are using the $\mathrm{T}$ or the $\mathrm{V}$ forms. (Tegez/Magáz/Önöz (Hungarian) - Tыкать/Bыкать (Russian) [Tykaty/Bykaty]).

Interestingly, in both languages the selection of formal/informal 'you' shall be made before greetings, since appropriate greetings are used according to the norms of T-V. In Hungary, Csókolom (literary 'I kiss') - is mostly used by children for the greetings of adults, while Jó napot kívánok - 'Good day' is used in adults' greetings (Szeleburdi család 'Giddy Family', 1981). Szia (for singular) or Sziasztok (for plural) are used as informal greetings (In Zártosztály 'Asylum', 2014). In the Russian language 3дравствуйе [Zdravstvujte] 'Hello' is used as formal greetings (Дневник мамь первоклассника 'Diary of a First-Grader's Mum', 2014). Привет [Privet] 'Hi' and Здравствуй [Zdravstvuj] 'Hello' are used as informal greetings (Черная молния 'Black Lightning', 2009, and Любовь-морковь 'Love-Carrot', 2007, respectively).

The selection of $\mathrm{T}$ or $\mathrm{V}$ forms in the studied languages also affects the conjugation of verbs, and, vice versa, the conjugation points out whether formal or informal 'you' is used, often without the actual use of any personal pronouns. (Ex. Jöjjön fel. 'Come up' and Перестаньте [perestan't'e'] 'Stop' are formal requests in Hungarian and Russian respectively in Szeleburdi család 'Giddy Family' (1981) and Дневник мамы первоклассника 'Diary of a First-Grader's Mum' (2014).

In the Hungarian language the T-V forms have their singular and plural forms as well: $T e$ (you - singular, informal), $T i$ (you - plural, 
informal), Maga (You - singular, formal; colloquial, but it is a little rude; sometimes expresses superiority; in writing it is offensive.) Maguk (You - plural, formal; colloquial, but it is a little rude; sometimes expresses superiority; in writing it is offensive.) $\ddot{O} n$ (You singular, formal; colloquial - very formal; accepted in official letters), Önök (You - plural, formal; colloquial - very formal; accepted in official letters). The choice of Maga/ Maguk and Ön/Önök often depends on the level of education (Maga/Maguk mostly used by people with lower educational background). The level of formality of the situation is also considered (if it is lower, Maga/Maguk may be used.) The mode of communication also matters. It is important to distinguish between colloquial and written forms. In official letters, the use of Maga/Maguk would have been proscribed.

The informal 'you' in Hungarian is used in informal situations, for example, in conversations among family members. Its use, however, is mostly determined by the age of interlocutors or their relationship in the family. Children are always addressed with the informal 'you': Egyél, mielött elmész. 'Please eat before you leave.' (Zártosztály 'Asylum', 2014). Adults with their adult interlocutors will follow several rules. If they are from different generations, the elder ones may use both the informal and formal address forms.

In earlier Hungarian films, it is portrayed that a younger family member used to address his or her elder family member using formal 'you' (Kemény kalap és krumpliorr 'Clown Hat and red Nose', 1978). In recent days, however, they more often use the informal 'you': Anya, mit csinálsz? 'What are you doing, mum?' (Zártosztály 'Asylum', (2014)).

The informal 'you' is used between friends and acquaintances, too. Children and students, or young(er) people of the same age use it regardless of the situation (Ámbár tanár úr "Teacher "Although" (1998)). Elder interlocutors use it only if they have had an opportunity earlier to agree to do so. The use of the informal 'you' without the "official" agreement about its use is considered to be very rude: Állj már odébb! 'Get away!' in Csak szex és más semmi 'Just Sex and Nothing Else' (2005). 
Analysing films made ten to fifteen years ago such as Argó (2007), one can observe that in insults only informal 'you' is used. It is important to state that films before the 1990s hardly displayed uncensored speech.

In basic schools, children are always addressed by the informal you, while they must use the formal one. In secondary schools some teachers use formal 'you' addressing students: László fiam, maga, szedje össze magát... Beszélnem kell a szüleivel 'You, Laszlo... Pull yourself together. I must talk to your parents'. ( $A z$ 5. iz 'The $5^{\text {th }}$ taste', 2014). Other teachers prefer the use of informal 'you': Vigyázz a szádra! 'Mind your language!' Nézzétek át őket! 'Revise them.' (Zártosztály 'Asylum', 2014).

In workplaces, co-workers will use both formal and informal 'you'. The formal 'you' is used at the beginning, but persons of higher status, ladies or older people have the right to offer the use of informal 'you' to their partners. The hierarchy is more important in this case than age or gender. Elderly people may address their younger colleagues using the informal 'you'. In such cases the younger colleague may address others using any 'you', depending on their relationship. Generally, if an elder person uses the informal 'you', it means that: 1 . He/she is much older, than the interlocutor. 2. He/she knows the interlocutors for a very long time. 3 . He/she offers the interlocutor the opportunity to use also the informal 'you'. In the first two cases the younger interlocutor will use the formal 'you' in address forms towards this person, while in the third option the use of informal 'you' will be accepted: Hogy kerülsz te ide? 'How did you get here?' (Csak szex és más semi, 'Just Sex and Nothing Else', 2005). When a person of higher rank offers the use of informal 'you' to his or her subaltern, it is almost a must to accept it.

The Russian language, in comparison with Hungarian, uses a less

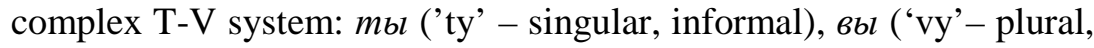
informal), and $B b l$ ('Vy' - singular/plural formal). The rules of the use of the formal and informal 'you' are quite similar to the Hungarian ones, however, there exist differences, too. 
The informal 'you' is used in informal situations in the family and between friends. Children address adults with the formal 'you', except from their parents, or, sometimes grandparents; they are addressed with the informal 'you'. In the family, sons and daughters-in-law while addressing their spouses' parents should use the formal 'you', while they are usually addressed with the informal one. (Ex. Я nрошy $\underline{B a c}$ [Ja proshu Vas], 'Please', in Дневник мамы первоклассника 'Diary of a First-Grader's Mum', 2014).

One of the main clear differences between the use of T-V in Hungary and Russia can be observed in shops and in schools (during communication of parents). While in Hungary the youth and people of age 30-50 may use the informal 'you', in Russia shops, schools, etc. are strongly considered as official places; therefore, the use of the formal 'you' is required (Csak szex és más semmi 'Just Sex and Nothing Else', 2005 and Дневник мамы первоклассника 'Diary of a First-Grader's Mum', 2014) .

Children and students must always address their teachers and lecturers using the formal 'you': Bbl позволите? [Vy pozvolite?] 'Will you let me'? (Тариф «счастливая семья» Promotion "Нарру Family", 2013). Teachers use the informal 'you' to address their pupils, while lecturers use the formal one to address their students (Дневник мамы первоклассника 'Diary of a First-Grader's Mum', 2014). Young people first use the formal 'you' and later the informal 'уоu' (Проездной билет 'Monthly ticket', 2011).

In offices and other workplaces, the use of the formal 'you' is widespread for everyone even for co-workers. (Ex. ...Bbl всё в гипсе, [Vy vsyo v gipse] '....and you are still in POP', in Дневник мамь первоклассника 'Diary of a First-Grader's Mum', 2014). However, when an older colleague uses the informal 'you' in Russia, younger colleagues will hardly respond with it: Я рад тебя видеть... Я Вам путёвку принёс [Ja rad tebja videt'... Ja Vam putjovku prinjos.] 'I'm glad to see you ... I brought you a ticket.' (Тариф «счастливая семья» Promotion "Happy Family", 2013). Also, when a person in a higher position uses informal 'you' while addressing his or her subaltern, the latter will hardly use the same. It is often heard that in 
these situations the subaltern uses formal address forms. $\underline{\text { Вы }}$ же меня знаете.... А что же для тебя вовремя?[Vy zhe menja znaete.... A chto zhe dlja tebja vovremja?] 'But you know me... And what 'in time' means for you?' (Любовь-морковь - 2 'Love-Carrot - 2' (2008)).

As in Hungarian, in the Russian language in insults only the informal 'you' is used: $\underline{T b l}$, что, коза [Ty, chto, koza] 'Hey, you, goat', (Проездной билет 'Monthly ticket', 2011).

The use of formal or informal 'you' demonstrates the 'good' or 'bad' relationship between the interlocutors. After their separation, the former wife uses the formal 'you' while addressing her divorced husband (Kypbep 'Courier' (1986).

The above discussed T-V system in the form that is used in the Hungarian and Russian languages does not exist in the English language. However, there are circumstances when one can clearly distinguish between formal and informal situations even without the use of the different 'vous'.

\section{Conclusion}

As stated above, the correct use of the formal and informal 'you' is essential in both Hungarian and Russian languages. The decision on the use of $\mathrm{T}$ or $\mathrm{V}$ should be made before greeting, since different greetings are used with people to whom one addresses as $\mathrm{T}$ and different as V. The T/V system also affects the conjugations, and this demonstrates the indirect address system of these languages.

While comparing similar situations in the earlier and relatively new films, it was observed that in the earlier films the formal 'you' was used more often. This observation indicates that the language etiquette in the two societies is still undergoing some changes, though the Russian one entertains more formal situations than the Hungarian one.

References

2011. Évi népszámlálás. 3. Országos adatok. Központi Statisztikai Hivatal Budapest, 2013 
http://www.ksh.hu/docs/hun/xftp/idoszaki/nepsz2011/nepsz_03_00_2011.pdf Accessed 16/07/2014

Balogh, Gy. A magyar film születésétől 1945-ig http://www.filmkultura.hu/regi/2000/articles/essays/balogh.hu.html Accessed 04/08/2015

Brown P. \& Levinson S.C.: Politeness. Some universals in language use. Cambridge: Cambridge University Press, 1987.

Brown, R., Gilman, A. 1975. A hatalom és a szolidaritás névmásai. In: Pap MáriaSzépe György (szerk.): Társadalom és nyelv. Szociolingvisztikai írások. Gondolat Kiadó. Budapest. 359-388.

Csajbok-Twerefou, I. 2010. The Role of Films in the Teaching of Foreign Languages. In: Legon Journal of the Humanities, Vol.21. Accra, Ghana, pp. 51-75.

Csajbok-Twerefou, I. \& Dzahene-Quashie, J. 2014. Glocalization of Western Popular Culture in Russia and Tanzania. In: New Perspectives on African Humanity: Beliefs, Values \& Artistic Expression. Editors: Gordon S.K. Adika, George Ossom-Batsa \& Helen Yitah. University of Ghana, Adwinsa Publications (Gh.) Ltd. pp. 109-133.

Fedorov, A.V. 2011. Федоров А.В.,Российское кино: очень краткая история,История кино10 февраля 2011 http://www.kinoteatr.ru/kino/art/kino/175/ Accessed: 8/05/2012

Félix-Brasdefer, C. Discourse Pragmatics. 2007. Language and culture resources for instructors, students and researchers of Spanish language. Politeness. http://www.indiana.edu/ discprag/polite.html Accessed 29/08/2015

Hitchings, H. 2013. Sorry! The English and Their Manners http://books.google.co.uk/books?id=SG4qpwpAB84C\&printsec=frontcover\&dq=i sbn: $1848546661 \& \mathrm{hl}=\mathrm{de} \& \mathrm{sa}=X \& \mathrm{ei}=\mathrm{vpDGU6K1OcK9ygOz5ICYDw \& ved=0CCE}$ Q6AEwAA\#v=onepage\&q\&f=false Accessed 16/07/2014

Lugovoy, А.А. 2001. Луговой А.А., Массовая культура: Россия-Запад.Российская массоваякультура конца XX века. Материалы круглого стола. 4 декабря 2001 г. Санкт-Петербург. СПб.: Санкт-Петербургское философское общество. 2001. C. http://anthropology.ru/ru/texts/lugovoi/masscult $16 . \mathrm{html}$ Accessed: $16 / 04 / 2012$

Macmillan

Online

Dictionary. http://www.macmillandictionary.com/dictionary/british/popular-culture

Sak, M. 2012. Зак М., Русское кино 1896-1917 http://www.russkoekino.ru/books/ruskino/ruskino-0001.shtml_Accessed: $31 / 03 / 2012$

The Maxims of Good Discourse by vizier Ptahhotep (ca. 2200 BCE) http://www.maat.sofiatopia.org/ptahhotep_maxims.htm Accessed 16/07/2014 
The Maxims of Ptahhotep by the Editors of The Encyclopædia Britannica http://www.britannica.com/EBchecked/topic/370565/The-Maxims-of-Ptahhotep Accessed 16/07/2014

Toshchenko, J.T. 2010. General and special Russian and Turkic civilization: the problem of glocalization. Scientific forums. III Congress of Sociologists of the Turkic world,"Globalization and the Turkic world." Bulletin of the Institute of Sociology, number 1, pp. 466-478 December 2010

Vlasyan, G.R. 2011. Власян, Г. Р. Коммуникативная категория вежливости: Проблема интерпретации Вестник Челябинского государственного университета. 2011. № 33 (248). Филология. Искусствоведение. Вып. 60. С. 36-38. 01/04/2014.

Всероссийская перепись населения $2010 \quad$ год http://www.gks.ru/free_doc/new_site/perepis2010/croc/Documents/Vol4/pub-0401.pdf Accessed 19/07/2014 